\title{
Nitrification rates in Arctic soils are associated with functionally distinct populations of ammonia-oxidizing archaea
}

\author{
Ricardo J Eloy Alves ${ }^{1}$, Wolfgang Wanek ${ }^{2}$, Anna Zappe ${ }^{1}$, Andreas Richter ${ }^{2}$, \\ Mette M Svenning ${ }^{3}$, Christa Schleper ${ }^{1}$ and Tim Urich ${ }^{1}$ \\ ${ }^{1}$ Department of Genetics in Ecology, University of Vienna, Vienna, Austria; ${ }^{2}$ Department of Terrestrial \\ Ecosystem Research, Faculty of Life Sciences, University of Vienna, Vienna, Austria and ${ }^{3}$ Department of \\ Arctic and Marine Biology, Faculty of Biosciences, Fisheries and Economics, University of Tromsø, Tromsø, \\ Norway
}

\begin{abstract}
The functioning of Arctic soil ecosystems is crucially important for global climate, and basic knowledge regarding their biogeochemical processes is lacking. Nitrogen $(\mathrm{N})$ is the major limiting nutrient in these environments, and its availability is strongly dependent on nitrification. However, microbial communities driving this process remain largely uncharacterized in Arctic soils, namely those catalyzing the rate-limiting step of ammonia $\left(\mathrm{NH}_{3}\right)$ oxidation. Eleven Arctic soils were analyzed through a polyphasic approach, integrating determination of gross nitrification rates, qualitative and quantitative marker gene analyses of ammonia-oxidizing archaea (AOA) and bacteria (AOB) and enrichment of $A O A$ in laboratory cultures. AOA were the only $\mathrm{NH}_{3}$ oxidizers detected in five out of 11 soils and outnumbered $A O B$ in four of the remaining six soils. The $A O A$ identified showed great phylogenetic diversity and a multifactorial association with the soil properties, reflecting an overall distribution associated with tundra type and with several physico-chemical parameters combined. Remarkably, the different gross nitrification rates between soils were associated with five distinct AOA clades, representing the great majority of known AOA diversity in soils, which suggests differences in their nitrifying potential. This was supported by selective enrichment of two of these clades in cultures with different $\mathrm{NH}_{3}$ oxidation rates. In addition, the enrichments provided the first direct evidence for $\mathrm{NH}_{3}$ oxidation by an $\mathrm{AOA}$ from an uncharacterized ThaumarchaeotaAOA lineage. Our results indicate that AOA are functionally heterogeneous and that the selection of distinct AOA populations by the environment can be a determinant for nitrification activity and $\mathrm{N}$ availability in soils.
\end{abstract}

The ISME Journal (2013) 7, 1620-1631; doi:10.1038/ismej.2013.35; published online 7 March 2013

Subject Category: Microbial ecology and functional diversity of natural habitats

Keywords: ammonia-oxidizing archaea; arctic soils; amoA; Thaumarchaeota; nitrification; ${ }^{15} \mathrm{~N}$ pool dilution

\section{Introduction}

Arctic and boreal ecosystems cover $22 \%$ of the land surface on Earth and are currently undergoing dramatic changes that are predicted to increase drastically in the following century, as a result of the rising temperatures disproportionally affecting these regions (Chapin et al., 2000; Sala et al., 2000; Intergovernmental Panel on Climate Change, 2007). Estimates indicated that the carbon (C) stored in permafrost soils in Arctic and boreal regions is more than twice the atmospheric C (Tarnocai et al., 2009).

Correspondence: C Schleper, Department of Genetics in Ecology, University of Vienna, Althanstrasse 14, Vienna 1090, Austria. E-mail: christa.schleper@univie.ac.at

Received 28 September 2012; revised 29 January 2013; accepted 31 January 2013; published online 7 March 2013
Higher emissions of carbon dioxide $\left(\mathrm{CO}_{2}\right)$ from soils through respiration are predicted to become a positive feedback to climate warming, as a result of increased soil organic matter decomposition and consequent higher nutrient availability (Binkley et al., 1994; Mack et al., 2004; Biasi et al., 2008; Schuur et al., 2008; Schuur et al., 2009). However, the extent of possible feedback effects will depend greatly on the response of the microbial populations driving the biogeochemical processes underlying nutrient fluxes (Singh et al., 2010; Xu et al., 2011).

A vast body of evidence shows that $\mathrm{N}$ is the major limiting nutrient in Arctic soils (Shaver and Chapin, 1980; Nordin et al., 2004), and its availability is dependent on decomposition processes and transformations of $\mathrm{N}$ compounds catalyzed by microorganisms (Canfield et al., 2010). Nitrification, the conversion of $\mathrm{NH}_{3}$ via nitrite $\left(\mathrm{NO}_{2}^{-}\right)$to nitrate 
$\left(\mathrm{NO}_{3}^{-}\right)$, has been documented in Arctic soils (for example, (Binkley et al., 1994; Chapin, 1996)), where it can consume up to half of the $\mathrm{N}$ mineralized annually (Giblin et al., 1991). Nitrification is also directly and indirectly involved in the production of the potent greenhouse and ozone-depleting gas nitrous oxide $\left(\mathrm{N}_{2} \mathrm{O}\right)$ (Conrad, 1996; Ravishankara et al., 2009), and it has been shown to contribute most of the $\mathrm{N}_{2} \mathrm{O}$ emitted from some soils (for example, (Martikainen, 1985; Mathieu et al., 2006)), including Arctic soils (Ma et al., 2007; Siciliano et al., 2009). However, nitrification is strongly dependent on the environmental conditions (Booth et al., 2005) and so are the fluxes of $\mathrm{N}$ compounds that it mediates.

Oxidation of $\mathrm{NH}_{3}$, the rate-limiting step of nitrification, is performed by members of both Bacteria and Archaea, although their relative contributions to nitrification in natural environments remain unclear (Prosser and Nicol, 2008; Schleper and Nicol, 2010). Archaea encoding the ammonia monooxygenase (AMO) and belonging to the phylum Thaumarchaeota (Brochier-Armanet et al., 2008) are widely distributed and highly abundant in several environments, often greatly outnumbering ammonia-oxidizing bacteria (AOB; for example, (Leininger et al., 2006; Wuchter et al., 2006)). In contrast to the knowledge on the physiology and metabolic properties of AOB (Arp et al., 2007), the ecophysiology and functional diversity of ammonia-oxidizing archaea (AOA) remains largely uncharacterized. Two isolates (Könneke et al., 2005; Tourna et al., 2011) and few enrichment cultures of AOA (Blainey et al., 2011; de la Torre et al., 2008; Hatzenpichler et al., 2008; Jung et al., 2011; LehtovirtaMorley et al., 2011) confirmed the capability of $\mathrm{NH}_{3}$ oxidation by certain lineages of Thaumarchaeota, preferably at low ammonium $\left(\mathrm{NH}_{4}^{+}\right)$concentrations. However, recent environmental studies suggested that not all Thaumarchaeota are $\mathrm{NH}_{3}$ oxidizers or that they might be capable of using alternative energy (Mußmann et al., 2011; Pratscher et al., 2011; Xia et al., 2011) and C sources (Ingalls et al., 2006; Tourna et al., 2011). It remains thus unknown whether AOA population structure affects their contribution to nitrification, as it was shown for other functional groups (Reed and Martiny, 2007; Strickland et al., 2009), including AOB (Horz et al., 2004).

Although AOA have been identified in Arctic permafrost-affected soils (Siciliano et al., 2009; Lamb et al., 2011; Banerjee and Siciliano, 2012), their populations and role in nitrification remain largely uncharacterized, despite the critical importance of $\mathrm{N}$ cycling in these ecosystems. Therefore, we aimed to characterize $\mathrm{AOA}$ populations and activity in 11 different Arctic soils through a polyphasic approach, integrating qualitative and quantitative marker gene analyses, determination of gross in situ and potential nitrification rates and cultivation attempts. We found distinct phylogenetic clades of AOA in different soil types, where they were a determinant of nitrification activity and, thus, of potential response mechanisms to environmental changes in these ecosystems. Our observations have implications not only for Arctic permafrost-affected soils but also for other environments where AOA are the dominant $\mathrm{NH}_{3}$ oxidizers.

\section{Materials and methods}

Sampling sites and soil physico-chemical parameter determination

Soil samples were collected from three distant Arctic geographic locations: Spitsbergen, in the Svalbard archipelago $\left(78^{\circ} \mathrm{N}\right)$, the main study-site; Zackenberg, in the eastern coast of Greenland $\left(74^{\circ} \mathrm{N}\right)$, and Tazovskiy, in western Siberia $\left(67^{\circ} \mathrm{N}\right)$. Sampling was performed in August 2009. The sampling sites covered some of the most common Arctic terrestrial landscapes, each characterized by distinct geomorphologies, water regimes and vegetation type: dry and wet moss tundra sites (Longyearbyen, Spitsbergen), shrub tundra (Tazovskiy, Zackenberg and Hotelneset in Spitsbergen), tussock tundra (Adventalen in Spitsbergen), tundra fens (Solvatnet and Knudsenheia in Spitsbergen) and frost boil upwellings (Solvatnet and Knudsenheia in Spitsbergen). Field sites' and description, as well as sampling procedures are described in detail in Supplementary Information. Soil pH, gravimetric water content (moisture \%) and $\mathrm{NH}_{4}^{+}, \mathrm{NO}_{3}^{-}$, $\mathrm{NO}_{2}^{-}$, dissolved organic carbon (DOC) and total dissolved nitrogen (TDN) concentrations were determined following standard procedures, as described in Hood-Nowotny et al. (2010) (see Supplementary Information for details). Dissolved inorganic nitrogen was calculated as the sum of $\mathrm{NH}_{4}^{+}$and $\mathrm{NO}_{3}^{-}$, and dissolved organic nitrogen (DON) was obtained by subtracting the dissolved inorganic nitrogen from the TDN.

In situ and potential gross nitrification Gross nitrification rates were determined by a ${ }^{15} \mathrm{~N}$ pool dilution assay, as described by Inselsbacher et al. (2007). In situ gross nitrification rates were measured in soil slurries under native $\mathrm{N}$ conditions, and potential rates were determined after amendment with $\mathrm{NH}_{4} \mathrm{Cl}$ to a final concentration of 1.7$2.5 \mathrm{~mm}$. Five replicate reactions were performed for each soil and nitrification rates were determined after incubation over a period of $20 \mathrm{~h}$ at $15^{\circ} \mathrm{C}$. This temperature is similar to the highest values measured in the region during the warm season (Westermann et al., 2011). Detailed procedures of the ${ }^{15} \mathrm{~N}$ pool dilution method are described in Supplementary Information. Net nitrification rates were calculated from the $\mathrm{NO}_{3}^{-}$pools measured during the ${ }^{15} \mathrm{~N}$ pool dilution assay, which were also used for modeling the gross rates.

Enrichment of AOA in laboratory cultures

Soil samples from the top soil layers of all Spitsbergen sites were used to inoculate 48 initial 
enrichment cultures. Four cultures were initiated from each soil by inoculating $20 \mathrm{ml}$ of fresh water medium (see Supplementary Information for medium composition) with $1 \mathrm{~g}$ of soil in sterile plastic vials. Initial cultures were incubated in pairs at 20 or $32{ }^{\circ} \mathrm{C}$ with either 0.2 or $0.5 \mathrm{mM} \mathrm{NH}_{4} \mathrm{Cl}$. All subsequent sub-cultures were supplemented with $0.5 \mathrm{mM} \mathrm{NH}_{4} \mathrm{Cl}$. All cultures were supplemented with $\mathrm{NaHCO}_{3}(2 \mathrm{~mm})$ as sole $\mathrm{C}$ source and with streptomycin $\left(50 \mu \mathrm{g} \mathrm{ml}^{-1}\right)$. In a second enrichment stage, 30 sub-cultures were incubated at 14 or $20^{\circ} \mathrm{C}$, and in a third enrichment stage, 32 sub-cultures were incubated in groups of nine at 4,20 or $28{ }^{\circ} \mathrm{C}$ and treated with either ampicillin $\left(100 \mu \mathrm{g} \mathrm{ml}^{-1}\right)$ or lysozyme (16.7 $\mathrm{mg} \mathrm{ml}^{-1}$ ), in addition to streptomycin. $\mathrm{NH}_{4}^{+}$and $\mathrm{NO}_{2}^{-}$concentrations were measured in all cultures at several time points with the methods described above. Cultures with stable $\mathrm{NH}_{3}$ oxidation activity were continuously subcultured at $20^{\circ} \mathrm{C}$ in the laboratory for approximately 3 years. Detailed incubation conditions of all subcultures and acetylene treatment are described in Supplementary Information.

Cloning PCR, sequencing and quantitative PCR Amplification of archaeal amoA genes for cloning and sequencing was performed with the newly designed primers Arch-amoA-7F (5'-ATGGTCTGGB TDAGAMG-3') and Arch-amoA-638R (5'-GCRGCCA TCCATCTRTA-3') (see Supplementary Information for primer design details). Detection of bacterial amo $A$ genes was performed with the primers amoA1F*/amoA-2 R (Rotthauwe et al., 1997; Stephen et al., 1999). Thaumarchaeal 16S rRNA genes were amplified with primers A109F (Großkopf et al., 1998) and Cren-957 R (Ochsenreiter et al., 2003). Quantitative PCR of archaeal amoA genes was performed with modified versions of primers $104 \mathrm{~F}$ (Tourna et al., 2011) and CrenamoA-616r (Tourna et al., 2008), hereafter named Arch-amoA-104F (5'-G CAGGAGACTAYATHTTCTA-3') and Arch-amoA616R (5'-GCCATCCATCTRTADGTCCA-3'), respectively. Modifications were made in order to cover most nucleotide base variation in the sequences obtained from the soils studied here. Quantitative PCR of bacterial amo $A$ and thaumarchaeal $16 \mathrm{~S}$ rRNA genes were performed with primers amoA1F/amoA-2R (Rotthauwe et al., 1997) and 771F/ 957R (Ochsenreiter et al., 2003), respectively. All molecular, phylogenetic and statistical analyses are described in detail in Supplementary Information.

\section{Data deposition}

The sequences reported in this paper have been deposited in the GenBank database (accession nos. JX426266-JX426615 and KC559122-KC559431).

\section{Results}

\section{Soil physico-chemical properties}

Eleven tundra soil samples were collected mainly from Spitsbergen (Svalbard), and also from Tazovskiy (Siberia) and Zackenberg (Greenland), and categorized according to ecosystem type (Table 1 and Supplementary Table S1; see Supplementary Information for site descriptions). The majority of the soils were dry, with the exception of the waterlogged tundra fen peat sites (Sol-tf and Knutf) and one moss tundra site (Lon-mt1). Soil pH values ranged between 3.7 and 8.4, with the lowest values observed in shrub tundra soils (Hot-st and Taz-stol) (Supplementary Table S1). Concentrations of DOC and TDN were low in the mineral soils (frost boils and moss, shrub and tussock tundra), ranging between 38 and $85 \mu \mathrm{g} \mathrm{Cg}^{-1} \mathrm{dw}$ soil and 10-30 $\mu \mathrm{g} \mathrm{N} \mathrm{g}^{-1} \mathrm{dw}$ soil, respectively, whereas the fen peat samples contained DOC and TDN concentrations within a much higher range (465-939 $\mu \mathrm{g} \mathrm{Cg}^{-1}$

Table 1 Soil sample description and $\mathrm{NH}_{3}$ oxidizer abundance

\begin{tabular}{|c|c|c|c|c|}
\hline \multirow[t]{2}{*}{ Sample } & \multirow[t]{2}{*}{ Location } & \multirow[t]{2}{*}{ Ecosystem type } & \multicolumn{2}{|c|}{$\operatorname{amoA}_{\text {copies }^{\mathrm{a}, \mathrm{b}}}$} \\
\hline & & & Archaea & Bacteria \\
\hline Hot-st & Hotelneset (Svalbard) & Shrub tundra (mineral soil) & $8 \times 10^{6} \pm 1 \times 10^{6}$ & ND \\
\hline Adv-tt & Adventalen (Svalbard) & Tussock tundra (mineral soil) & $4 \times 10^{7} \pm 2 \times 10^{6}$ & ND \\
\hline Lon-mt1 & Longyearbyen (Svalbard) & Moss tundra (mineral soil in wet ridge) & $3 \times 10^{6} \pm 1 \times 10^{6}$ & ND \\
\hline Lon-mt2 & & Moss tundra (mineral soil in dry mount) & $5 \times 10^{7} \pm 8 \times 10^{6}$ & $5 \times 10^{5} \pm 1 \times 10^{5}$ \\
\hline Lon-mt3 & & & $2 \times 10^{8} \pm 2 \times 10^{7}$ & $5 \times 10^{5} \pm 7 \times 10^{4}$ \\
\hline Sol-tf & Solvatnet (Svalbard) & Tundra fen peat (organic soil) & ND & $2 \times 10^{6} \pm 3 \times 10^{5}$ \\
\hline Sol-fb & & Frost boil in tundra fen (mineral soil) & $2 \times 10^{7} \pm 8 \times 10^{6}$ & $2 \times 10^{6} \pm 2 \times 10^{5}$ \\
\hline Knu-tf & Knudsenheia (Svalbard) & Tundra fen peat (organic soil) & $<4 \times 10^{5 \mathrm{c}}$ & $2 \times 10^{6} \pm 1 \times 10^{5}$ \\
\hline Knu-fb & & Frost boil in tundra fen (mineral soil) & $2 \times 10^{6} \pm 3 \times 10^{5}$ & $4 \times 10^{5} \pm 6 \times 10^{4}$ \\
\hline Taz-sto & Tazovskiy (Western Siberia) & Shrub tundra (cryoturbated organic soil) & $1 \times 10^{7} \pm 3 \times 10^{6}$ & ND \\
\hline Zac-st & Zackenberg (Greenland) & Shrub tundra (mineral soil) & $4 \times 10^{7} \pm 3 \times 10^{5 d}$ & ND \\
\hline
\end{tabular}

Abbreviations: dw, dry weight; fw, fresh weight; ND, not detected.

${ }^{a}$ Values given as per g dw soil.

${ }^{b}$ Values expressed as arithmetic mean \pm s.d. from triplicate reactions.

${ }^{\mathrm{c} B e l o w}$ estimated quantification limit in the highest amount of template tested but detected with the end point PCR assay.

${ }^{\mathrm{d}}$ Value given as per g fw soil, as moisture content was not determined for the sample. 
dw and 139-192 $\mathrm{gg} \mathrm{Ng}^{-1} \mathrm{dw}$ soil, respectively) (Supplementary Table S1). However, the relative contribution of the different $\mathrm{N}$ compounds to the TDN pools was very variable (Supplementary Table S1). In shrub, tussock and moss tundra soils, $\mathrm{NH}_{4}^{+}$comprised most of the dissolved $\mathrm{N}$ (50-95\%), followed by DON (2-41\%) and very low fractions of $\mathrm{NO}_{3}^{-} \quad(3-9 \%)$. By contrast, $\mathrm{NO}_{3}^{-}$fractions were much higher in the fen peat and frost boil soils $(24-64 \%)$, accounting for most of the extractable $\mathrm{N}$ in the Sol-fb and Knu-tf samples (64\% and $60 \%$, respectively). Nitrite was below the detection limit in all the samples.

In situ and potential gross and net nitrification rates Gross nitrification under in situ N conditions was determined in eight distinct Arctic soils with a ${ }^{15} \mathrm{NO}_{3}^{-}$pool dilution assay and showed considerable rate variability between most soils, with great differences observed within small spatial scales (for example, tundra fen peat and frost boils) (Figure 1). Although also highly variable, in situ net nitrification rates were negative or close to zero in most soils, indicating a prompt consumption of the $\mathrm{NO}_{3}^{-}$produced (Supplementary Figure S1). In situ gross nitrification rates were lower in the dry mineral soils, with a rate 4-17-fold higher in the wet moss tundra soil and the overall highest rates in the waterlogged tundra fen peat soils, when compared on a dry soil/peat basis (3-7-fold higher than the highest rate in mineral soils) (Figure 1). Potential gross nitrification rates, assessed after amendment with $\mathrm{NH}_{4} \mathrm{Cl}$ to a final concentration of $\sim 2 \mathrm{mM}$, were also variable and were similar to the in situ rates in half of the soils, indicating that the nitrifier populations were not $\mathrm{NH}_{4}^{+}$-limited (Figure 1). However, potential rates were over sevenfold higher in the Sol-tf peat soil and 3-4-fold higher in the Hot-st shrub tundra and Knu-fb frost boil soils, thus showing a variability in response to $\mathrm{NH}_{4}^{+}$input that was irrespective of soil ecosystem type or moisture content (Figure 1 and Supplementary Table S1). Exclusively in the wet moss tundra soil (Lon-mt1), nitrification was almost completely inhibited by $\mathrm{NH}_{4}^{+}$addition (Figure 1). In situ gross and net nitrification rates were strongly negatively correlated $\left(R^{2}=0.96, P<0.0001\right.$; Supplementary Figure S2), showing that gross $\mathrm{NO}_{3}^{-}$consumption and production rates varied proportionally between the different soils. By contrast, potential gross and net nitrification rates were not correlated, showing that $\mathrm{NO}_{3}^{-}$production and consumption responded differently to $\mathrm{NH}_{4}^{+}$addition $\left(R^{2}=0.01, P=0.82\right.$; Supplementary Figure S2).

\section{Detection and quantification of $\mathrm{NH}_{3}$ oxidizers}

Archaeal amo $A$ genes (encoding the $\alpha$-subunit of the AMO enzyme) were detected in 10 of the 11 soils with newly designed PCR primers based on an
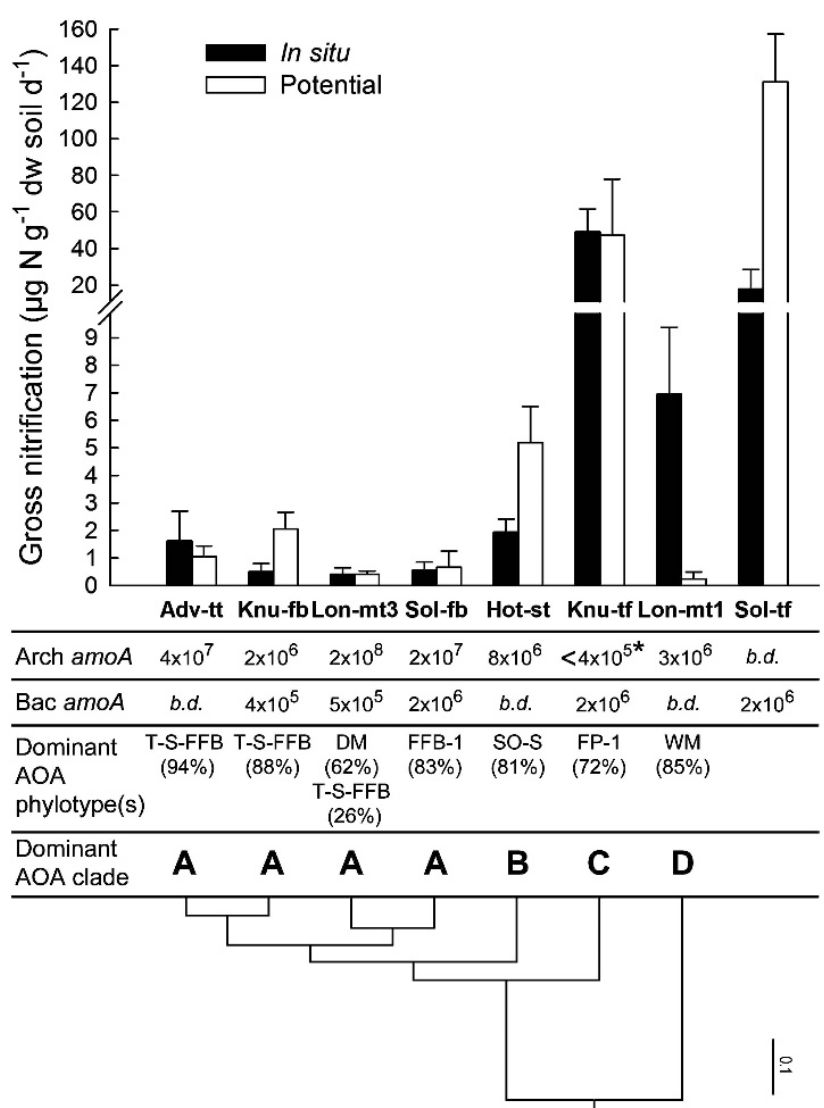

Figure 1 Relationship between gross nitrification and $\mathrm{NH}_{3}$ oxidizer populations. In situ and potential gross nitrification rates (without or with amendment with $\mathrm{NH}_{4} \mathrm{Cl}$ to a final concentration of 1.7-2.5 mM, respectively), abundance of AOA and AOB (amoA copies ${ }^{-1} \mathrm{dw}$ soil) and proportion of archaeal amo $A$ sequences associated with the dominant AOA clade in the clone library from each soil. The hierarchical clustering dendrogram represents relationships between AOA populations and is based on weighted UniFrac pairwise distances (with normalized branch weights). All nodes of the dendrogram have Jackknife support values of $100 \%$ (after 1000 permutations). The scale represents the distance between populations in UniFrac units. Arch, archaeal; Bac, bacterial; ND, not detected. *Below estimated quantification limit in the highest amount of template tested but detected with the end point PCR assay.

updated amoA gene database (Supplementary Information). By contrast, $\beta$-proteobacterial amo $A$ genes were detected only in six of the soils. Archaeal and bacterial amoA gene copy numbers ranged between $10^{6}-10^{8}$ and $10^{5}-10^{6}$ copies $g^{-1} \mathrm{dw}$ soil, respectively (Table 1). AOA outnumbered AOB by 1-3 orders of magnitude in soils where both were detected, namely in the frost boil and dry moss tundra soils. AOB dominated only the tundra fen peat soils, although AOA were detected in the Knudsenheia fen by end point PCR but were below quantification range of the quantitative PCR assay (Table 1).

AOA diversity and phylogenetic analysis

A total of 499 cloned archaeal amo $A$ genes were sequenced from 10 soil samples (50 clones per 
sample on average) and grouped into AOA phylotypes at $\geqslant 93 \%$ nucleotide identity level. Phylogenetic analysis revealed an overall broad phylogenetic representation of AOA in the sample set analyzed (Figure 2). The AOA phylotypes were distributed between five robust phylogenetic clades, mainly within the Nitrososphaera cluster (Pester et al., 2012), associated with the thaumarchaeal lineage I.1b. Based on DNA sequences, all clades had a bootstrap support $\geqslant 93 \%$ (Figure 2). Analysis on the protein level further supported all clades with bootstrap values between $64 \%$ and $86 \%$ (Supplementary Figure S4). Despite the broad phylogenetic diversity of the AOA phylotypes detected, the intra-sample diversity was generally low, even when coverage of the clone libraries was identical to, or approached, the predicted phylotype richness (Supplementary Figure S3; Supplementary Table S2). This was also evident in the low phylogenetic diversity (PD) indices, with the exception of the Lon-mt1, Knu-fb and Knu-tf samples, which harbored rare phylotypes associated with more dissimilar clades (Supplementary Table S2). The low diversity indexes reflected an uneven population composition resulting from the clear dominance of a single AOA phylotype in each population (Figure 2; Supplementary Table S2). Most dominant phylotypes showed great local

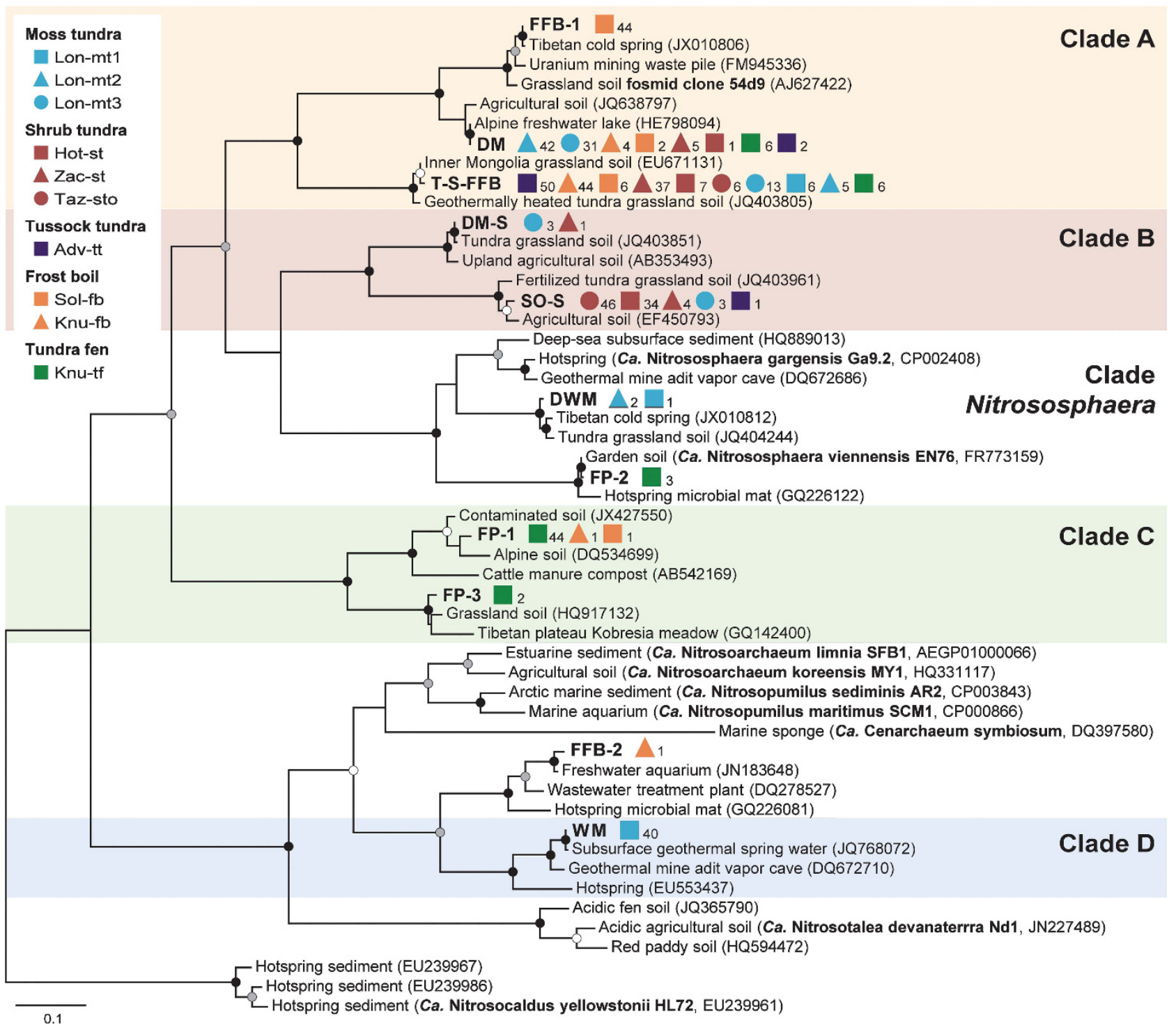

Figure 2 Maximum-likelihood phylogenetic tree of archaeal amoA. Phylogeny is based on 51 sequences (590-bp long) and includes a representative of each phylotype ( $\geqslant 93 \%$ nucleotide identity), closest BLAST hits with GenBank and major reference sequences. Tree was calculated based on the GTR + I + G model of DNA evolution (see Supplementary Information for details). Percentages of bootstrap replicates (1000 replicates) supporting the nodes are represented by filled circles: black, $\geqslant 90 \%$; gray, $\geqslant 80 \%$; and white, $\geqslant 70 \%$. Phylotypes from this study, sequences from cultured organisms and metagenomic clones are indicated in bold. Reference sequences are named as 'environmental source (accession number)'. Different symbols represent different samples and are color-coded according to soil ecosystem. Numbers following the symbols represent the number of sequences obtained from the sample associated with the respective phylotype. Names on the right-hand side of the tree represent the main AOA clades defined in this study. 
specificity, even between similar tundra soils, and few were shared only by a particular soil ecosystem, regardless of spatial scale or geographic location (that is, Hot-st and Taz-sto; Lon-mt2 and Lon-mt3). The majority of the sequences grouped within clade A, represented by the soil fosmid clone 54d9 (Treusch et al., 2005), and included the most abundant and widespread phylotype (T-S-FFB). This clade comprised nearly all sequences from the Spitsbergen frost boil, tussock and dry moss tundra samples, as well as from the Zackenberg shrub tundra. Clade B comprised, almost exclusively, sequences from shrub tundra, namely those dominating the Tazovskiy and Hotelneset samples. Clade C dominated the tundra fen peat from Knudsenheia and represents the only major AOA cluster without cultured representatives to date or 16S rRNA gene taxonomic affiliation (Pester et al., 2012). Clade D was associated with the Nitrosopumilus lineage and was only detected in the wet moss tundra soil, where it dominated the AOA population, and by a single sequence from the Knudsenheia frost boil (Figure 2). Only two rare phylotypes in moss tundra samples and in the tundra fen were affiliated with clade Nitrososphaera, which includes the cultured Ca. Nitrososphaera viennensis (Tourna et al., 2011) and Ca. Nitrososphaera gargensis (Hatzenpichler et al., 2008).

AOA distribution in relation to soil physico-

chemical properties

Potential relationships between AOA population composition and soil physico-chemical properties were inferred through unconstrained (that is, BIOENV) (Clarke and Ainsworth, 1993) and constrained (that is, CCA) multivariate methods, based on the relative abundance of the AOA phylotypes. Despite potential biases associated with the relatively small data set, the dominance of a single phylotype in most AOA populations suggested that the expected increase in diversity, as a result of a bigger data set, would exert little effect on the analysis. The BIOENV analysis showed that DOC/DON, moisture and DON had the best individual association with the composition of AOA distribution (Supplementary Table S3). The combination between moisture, $\mathrm{pH}, \mathrm{NO}_{3}^{-}$and $\mathrm{DON}$ showed the best association with AOA population structure, although with lower rank correlation coefficients than DOC/TDN alone (Supplementary Table S3). CCA analyses of all measured physico-chemical parameters also showed that moisture, $\mathrm{pH}, \mathrm{NO}_{3}^{-}$and $\mathrm{DON}$ combined yielded the most significant model explaining the highest percentage of variance in AOA distribution (model 1; Figure 3; Supplementary Tables S4 and S5). Analyses of ratio variables and non-redundant measured parameters yielded a significant model with $\mathrm{NO}_{3}^{-} / \mathrm{NH}_{4}^{+}$, DOC/TDN, moisture and $\mathrm{pH}$ (model 2), explaining a percentage of AOA distribution variance similar to that explained by model 1

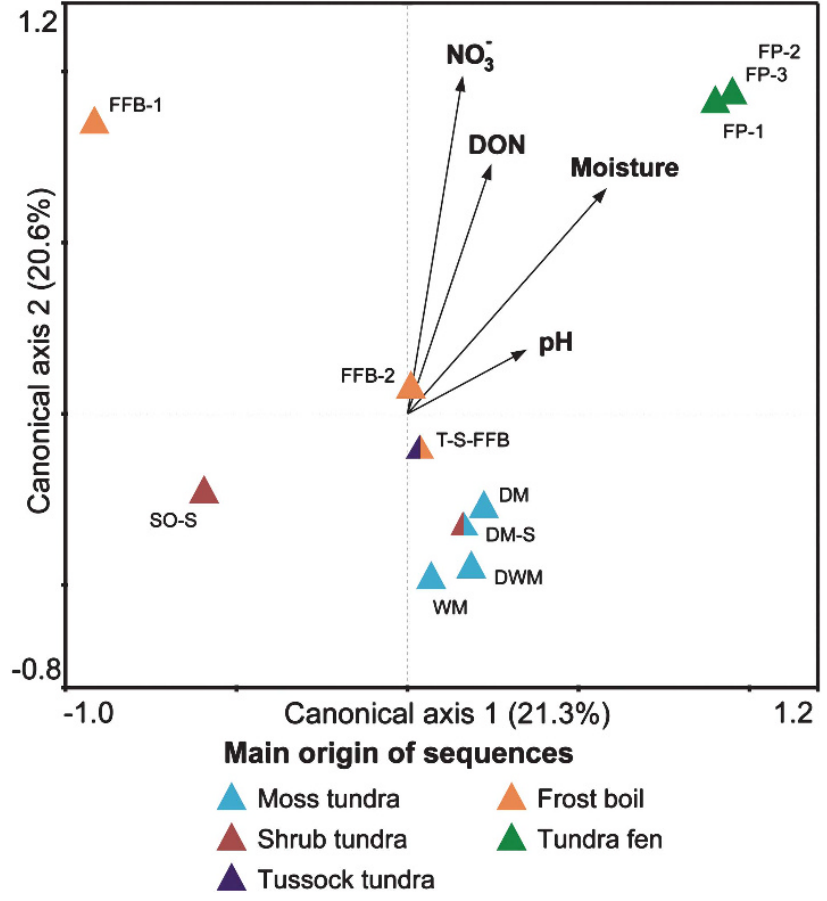

Figure 3 Relationship between AOA distribution and soil properties. CCA biplot of AOA phylotype relative abundances and selection of physico-chemical parameters (model 1). Symbols represent the $11 \mathrm{AOA}$ phylotypes and are color-coded according to major origin of sequences. Symbols with two colors correspond to phylotypes dominating two distinct soil types. Symbols with more than one phylotype name represent overlapping phylotypes. The percentages of phylotype distribution variance explained by the two principal canonical axes are represented close to the axes. Conditional variables are represented by the black arrows.

(69.4\% and $72.5 \%$, respectively) (Supplementary Figure S5; Supplementary Tables S4 and S5). Although none of the variables had individual significant explanatory power (Supplementary Table S5), both CCA models showed a similar separation between AOA phylotypes, which reflected a general distribution according to the combined effect of $\mathrm{pH}$, moisture and the $\mathrm{N}$ content of the soils, namely $\mathrm{NO}_{3}^{-}$(Figure 3 and Supplementary Figure S5).

AOA growth and $\mathrm{NH}_{3}$ oxidation activity in enrichment cultures

A total of 48 initial AOA enrichment cultures were set up from all the different Spitsbergen soils and sub-cultured at three different temperatures $\left(4,20\right.$ and $\left.28^{\circ} \mathrm{C}\right)$. Cultures from a frost boil soil (Knu$\mathrm{fb}$ ) and from a dry moss tundra soil (Lon-mt2) showed stable $\mathrm{NH}_{3}$ oxidation activity, with AOA being the only $\mathrm{NH}_{3}$ oxidizers detected after three enrichment stages (that is, no detectable AOB; Figure 4). The amo $A$ sequences detected in five enrichment cultures from these two soils clustered exclusively with phylotypes from clades A and C (Table 2; Supplementary Figure S6). Although clade 


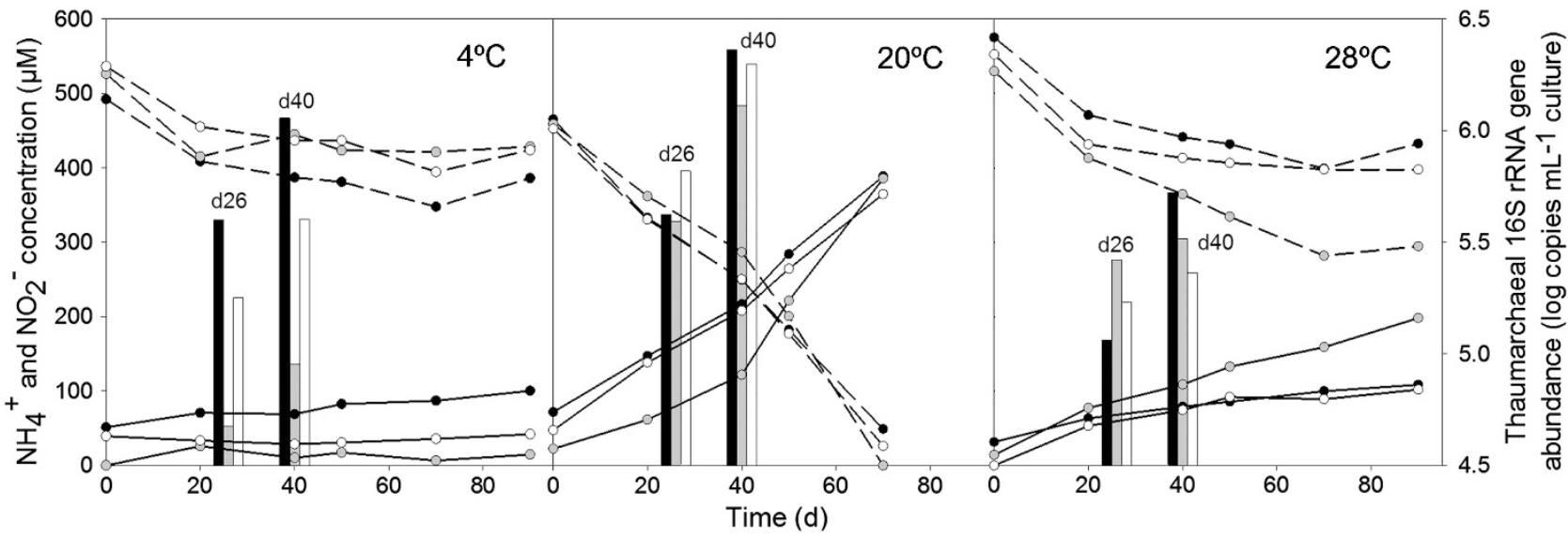

Figure 4 Growth and activity of $\mathrm{AOA}$ in enrichment cultures. $\mathrm{NO}_{2}^{-}$production (solid lines), $\mathrm{NH}_{4}^{+}$consumption (dashed lines) and thaumarchaeal 16S rRNA gene copies at days 26 and 40 (bars) in nine enrichment cultures from moss tundra (Lon-mt2) and frost boil (Knu-fb) soils incubated at 4,20 or $28^{\circ} \mathrm{C}$. Figures depict three example cultures out of nine cultures incubated at each temperature, exhibiting identical $\mathrm{NH}_{3}$ oxidation activity. AOB were not detected in any of the cultures. Filled circles and bars: black, Knu-fb cultures; gray and white, two different Lon-mt2 cultures, respectively.

Table 2 Thaumarchaeal growth, AOA clade affiliation and $\mathrm{NH}_{3}$ oxidation activity in nine enrichment cultures from moss tundra (Lon$\mathrm{mt2}$ ) and frost boil (Knu-fb) soils incubated at different temperatures

\begin{tabular}{|c|c|c|c|c|c|c|}
\hline \multirow{2}{*}{$\begin{array}{l}\text { Incubation } \\
\text { temperature }\end{array}$} & \multirow{2}{*}{$\begin{array}{l}\text { Original } \\
\text { soil }\end{array}$} & \multirow{2}{*}{$\begin{array}{c}16 S \text { rRNA gene } \\
\text { copies fold increase }\end{array}$} & \multirow{2}{*}{$\begin{array}{c}\mathrm{NH}_{4}^{+} \text {consumption } \\
\left(\mu \mathrm{N} \mathrm{NH}_{4}^{+} d^{-1}\right)\end{array}$} & \multirow{2}{*}{$\begin{array}{l}\mathrm{NO}_{2}^{-} \text {production } \\
\quad\left(\mu \mathrm{M} \mathrm{NO}_{2}^{-} d^{-1}\right)\end{array}$} & \multicolumn{2}{|c|}{ AOA clade (no. of sequences) } \\
\hline & & & & & $A$ & $C$ \\
\hline \multirow[t]{4}{*}{$4^{\circ} \mathrm{C}$} & Knu-fb & 2.8 & 1.07 & -0.10 & $17(94 \%)$ & $1(6 \%)$ \\
\hline & Lon-mt2 & 2.4 & 0.93 & -0.24 & $10(53 \%)$ & $9(47 \%)$ \\
\hline & Lon-mt2 & 1.8 & -1.48 & -0.79 & NA & NA \\
\hline & $\mathrm{AM} \pm \mathrm{SD}$ & $2.3 \pm 0.5^{\mathrm{a}}$ & $0.17 \pm 1.43^{\mathrm{a}}$ & $-0.38 \pm 0.36^{\mathrm{a}}$ & & \\
\hline \multirow{4}{*}{$20^{\circ} \mathrm{C}$} & Knu-fb & 5.4 & 4.18 & 3.48 & $8(42 \%)$ & $11(58 \%)$ \\
\hline & Lon-mt2 & 3.0 & 4.02 & 3.48 & $3(15 \%)$ & $17(85 \%)$ \\
\hline & Lon-mt2 & 3.3 & 3.75 & 3.02 & NA & NA \\
\hline & $\mathrm{AM} \pm$ s.d. & $3.9 \pm 1.3^{\mathrm{a}}$ & $3.98 \pm 0.22^{\mathrm{b}}$ & $3.33 \pm 0.27^{\mathrm{b}}$ & & \\
\hline \multirow[t]{4}{*}{$28^{\circ} \mathrm{C}$} & Knu-fb & 4.5 & 1.49 & 1.58 & $19(100 \%)$ & $0(0 \%)$ \\
\hline & Lon-mt2 & 1.4 & 0.92 & 1.05 & NA & NA \\
\hline & Lon-mt2 & 1.2 & 2.44 & 0.79 & NA & NA \\
\hline & $\mathrm{AM} \pm$ s.d. & $2.4 \pm 1.9^{\mathrm{a}}$ & $1.62 \pm 0.77^{\mathrm{a}}$ & $1.14 \pm 0.40^{\mathrm{c}}$ & & \\
\hline
\end{tabular}

Abbreviations: $\mathrm{AM} \pm \mathrm{SD}$, arithmetic mean \pm s.d.; NA, not available.

Thaumarchaeal 16S rRNA gene copy increase was determined between days 26 and 40, and $\mathrm{NH}_{4}^{+} \mathrm{Consumption}$ and $\mathrm{NO}_{2}^{-}$production rates were determined between days 20 and 40. Proportion of sequences affiliated with the two AOA clades detected (A and C) are expressed as percentage in each clone library. Lowercase letters indicate significant differences between temperatures: $16 \mathrm{~S}$ rRNA gene copies increase, $P=0.3297$;

$\mathrm{NH}_{4}^{+}$consumption, $P<0.01 ; \mathrm{NO}_{2}^{-}$production, $P<0.0001$.

A dominated the cultures at $4{ }^{\circ} \mathrm{C}$ and $28^{\circ} \mathrm{C}$, all cultures at $20^{\circ} \mathrm{C}$ were dominated by a single phylotype from clade C (Supplementary Figure S6). Thaumarchaeal growth, assessed by the increase in 16S rRNA gene copy numbers, was observed in all the cultures tested and not significantly different between cultures at the three different temperatures (Table 2). However, stable and continuous $\mathrm{NH}_{4}^{+}$ oxidation occurred only at $20^{\circ} \mathrm{C}$, as shown by the conversion of $\sim 500 \mathrm{mM} \mathrm{NH}_{4}^{+}$to $\mathrm{NO}_{2}^{-}$over a period of 70-100 days in nine independent cultures (Figure 4). No conversion of $\mathrm{NH}_{4}^{+}$to $\mathrm{NO}_{2}^{-}$was observed in cultures at $4{ }^{\circ} \mathrm{C}$, while at $28^{\circ} \mathrm{C}$ very slow rates were observed only during the initial 70 days $(50-150 \mu \mathrm{M})$. AOA enrichment cultures with stable $\mathrm{NH}_{3}$ oxidation activity at $20^{\circ} \mathrm{C}$ were continuously sub-cultured and maintained in the laboratory over a period of almost 3 years (Supplementary Figure S7). Forty-five identical archaeal amo $A$ sequences obtained from several replicate sub-cultures yielded only the clade C phylotype detected in earlier enrichment cultures (Supplementary Figure S6). This organism was enriched up to $39-49 \%$ of all prokaryotes present in several cultures (that is, $16 \mathrm{~S}$ rRNA gene copies ml ${ }^{-1}$ : $1.6 \times 10^{5}$ and $2.8 \times 10^{7}$ archaea out of $4.1 \times 10^{5}$ and $5.6 \times 10^{7}$ prokaryotes, respectively). $\mathrm{NO}_{2}^{-}$production and $\mathrm{NH}_{3}$ consumption were inhibited upon addition of acetylene, confirming the AMO-dependent oxidation of $\mathrm{NH}_{4}^{+}$ to $\mathrm{NO}_{2}^{-}$(Supplementary Figure S7). Twenty identical thaumarchaeal 16S rRNA gene sequences $(\geqslant 99.6 \%$ identity) amplified from the same cultures showed that the amo $A$ identified in clade $C$ belongs to an organism closely associated with the reference 
soil fosmid clone 29i4 (Quaiser et al., 2002; 98.498.7\% 16S rRNA identity; Supplementary Figure S8). Clone $29 i 4$ represents a thaumarchaeal lineage widespread in soils, although without cultured representatives to date.

\section{Discussion}

The regulation of $\mathrm{N}$-cycling processes, such as nitrification, is crucial for Arctic soil ecosystem functioning. Here, we have characterized AOA populations dominating $\mathrm{NH}_{3}$ oxidizer communities in a wide range of Arctic permafrost-affected soils through a polyphasic approach, which combined phylogenetic and abundance analyses of AOA with physico-chemical parameters, gross nitrification rates and laboratory cultivation. This integrated approach yielded five major outcomes: (1) high thaumarchaeal $\beta$-diversity and abundance were associated with most Arctic soil ecosystems analyzed, outnumbering AOB in most samples; (2) the composition of AOA populations was associated with several combined physico-chemical parameters; (3) AOA populations were linked to different gross nitrification rates; (4) AOA populations reacted differently to changes in $\mathrm{NH}_{4}^{+}$availability; and (5) both environmental and cultivation analyses supported different nitrification capabilities among AOA clades.

Prevalence of AOA among $\mathrm{NH}_{3}$ oxidizers in Arctic soils Our study showed a widespread distribution, high abundance and differential phylogenetic diversity of AOA across different Arctic soils. By contrast, $\beta$-proteobacterial $\mathrm{NH}_{3}$ oxidizers were surprisingly undetectable in nearly half of the soils analyzed, and orders of magnitude less abundant than AOA in most others, with the exception of the AOBdominated peat soils. Although it is possible that unknown AOB groups might have not been detected in the soils sampled, the primer set used here was recently shown to cover the groups of AOB typically found in soils (Junier et al., 2008). The overall prevalence of AOA and the presence of representatives of most major groups of soil AOA known strongly suggest that soils from cold environments might harbor common features that favor the general prevalence of thaumarchaea, as previously observed in alpine (Nemergut et al., 2008) and Canadian Arctic soils (Lamb et al., 2011; Banerjee and Siciliano, 2012). However, this needs to be confirmed by an extended survey.

\section{Physico-chemical determinants of AOA population composition}

The distribution of AOA phylotypes did not show geographic patterning between Svalbard, Greenland and Siberia sites or between the Svalbard sites but rather followed an 'ecosystem-type' (that is, habitat) distribution. However, further sample replication would be required to confirm geographical or ecosystem distribution patterns, which were not the main aim of the present work. Independent multivariate analyses showed a multifactorial association between overall AOA distribution and the soil properties. The combined effect of $\mathrm{pH}$ and soil moisture and $\mathrm{N}$ contents, namely $\mathrm{NO}_{3}^{-}$and $\mathrm{DON}$, suggested a general niche partitioning between AOA clades according to: dry (clade $\mathrm{A}$ and $\mathrm{B}$ ) or wet (clade D) mineral soils with low $\mathrm{N}$ (particularly $\mathrm{NO}_{3}^{-}$) and high DOC/TDN, and wet organic soils with high $\mathrm{N}$ (particularly $\mathrm{NO}_{3}^{-}$) and low DOC/TDN (clade C). Although $\mathrm{pH}$ has been shown to be an important determinant of AOA niche partitioning in other (non-Arctic) soils (Gubry-Rangin et al., 2011), individually, it had no significant explanatory power for overall AOA distribution in our analyses (Supplementary Tables 3 and 5). Despite the apparent $\mathrm{pH}$-associated selection of clade $\mathrm{B}$ in the acidic soils (Hot-st and Taz-sto; Figure 2 and Supplementary Table S1), $\mathrm{pH}$ only contributed to the resolution of AOA population composition when combined with several other soil properties. The particular association between AOA distribution and $\mathrm{NH}_{4}^{+} / \mathrm{NO}_{3}^{-}$, or $\mathrm{NO}_{3}^{-}$alone (Supplementary Table S5), was consistent with previous studies from non-Arctic soils reporting significant correlations between AOA population structure, or abundance, and $\mathrm{NO}_{3}^{-}$leaching (Wessén et al., 2011) and fertilization (Glaser et al., 2010). However, similar to these studies, the association between AOA and $\mathrm{NH}_{4}^{+} / \mathrm{NO}_{3}^{-}$, or $\mathrm{NO}_{3}^{-}$, did not reflect their clustering according to nitrification rates (Figures 1 and 3), and thus the relationships between AOA and these two factors appear to be independent. Our results indicate that the composition of soil AOA populations are likely not explained by single physicochemical properties and is rather dependent on the interplay between several environmental factors.

\section{Differences in activity among AOA clades}

The role in nitrification and niche adaptations of AOA (as compared with AOB) have been disputed since the discovery of their high abundances in soils (Leininger et al., 2006), with environmental studies often yielding contrasting results (for example, (Di et al., 2009; Jia and Conrad, 2009; Schauss et al., 2009; Kelly et al., 2011; Wessén et al., 2011; Szukics et al., 2012)). However, such studies have usually addressed AOA as a functionally homogeneous group although their diversity and distribution suggest a broader metabolic and physiological potential (Gubry-Rangin et al., 2011; Pester et al., 2012), as known for AOB (Arp et al., 2007). In line with this AOA heterogeneity, gross nitrification rates did not reflect the overall $\mathrm{NH}_{3}$ oxidizer abundance in the present Arctic soils. Rather, both in situ and potential nitrification rates were linked to AOA population structure in the AOA-dominated 
soils. For example, soils dominated by clade A exhibited the lowest nitrification rates, in spite of harboring the largest AOA populations, which was further supported by enrichment cultures of clade A with little or no nitrification activity. In soils where no AOB were detectable, we estimated 'cell-specific' nitrification rates for AOA based on $a m o A$ gene abundances and in situ gross nitrification rates. In soil Adv-tt, dominated by clade A, the rate was comparably low with $0.18 \mathrm{fmol} \mathrm{N}$ cell $^{-1}$ $\mathrm{h}^{-1}$, whereas the soils dominated by clade B (Hotst) and by clade D (Lon-Mt1) had 5.6-fold (1.0 fmol $\left.\mathrm{Ncell}^{-1} \mathrm{~h}^{-1}\right)$ and 55 -fold $\left(9.9 \mathrm{fmol} \mathrm{Ncell}^{-1} \mathrm{~h}^{-1}\right)$ higher cell-specific activities, respectively. The nitrification rate of $\mathrm{AOB}$ calculated with data from the Sol-tf soil was $30 \mathrm{fmol} \mathrm{N}$ cell $^{-1} \mathrm{~h}^{-1}$, in line with the higher rates reported for this group.

The different responses to $\mathrm{NH}_{4}^{+}$amendment in soils where no $\mathrm{AOB}$ were detectable indicated also a niche partitioning between AOA clades regarding $\mathrm{NH}_{4}^{+}$concentration. For instance, addition of $\mathrm{NH}_{4}^{+}$induced a threefold higher nitrification rate in the soil dominated by clade B but did not affect the soil dominated by clade A, although in situ rates were similar in both (Figure 1). This indicated that clade $\mathrm{B}$ was $\mathrm{NH}_{4}^{+}$-limited and that it has a higher nitrification potential than clade A. Moreover, the low $\mathrm{NH}_{4}^{+}$amount added (up to $\sim 2 \mathrm{~mm}$ ) strongly inhibited nitrification in the Lon-mt1 soil dominated by clade $\mathrm{D}$, which showed rates among the highest under in situ $\mathrm{NH}_{4}^{+}$concentrations. This is in agreement with the fact that clade $\mathrm{D}$ is associated with the lineage represented by the isolate $\mathrm{Ca}$. Nitrosopumilus maritimus, which is inhibited at $\mathrm{NH}_{4}^{+}$concentrations of 2-3 mM (Martens-Habbena et al., 2009).

Taken together, our data indicated that AOA from clade A, which are represented by the fosmid clone 54d9 (Treusch et al., 2005) and constitute the most abundant and widespread AOA in soils (Bates et al., 2011), possibly do not obligately or exclusively grow as $\mathrm{NH}_{3}$ oxidizers. This was consistently supported by their very low nitrification activity in situ (that is, Adv-tt soil) and in enrichment cultures, as well as their lack of response to $\mathrm{NH}_{4}^{+}$amendment. In line with this, studies to date showing direct evidence for autotrophic $\mathrm{NH}_{3}$ oxidation by soil AOA (Jung et al., 2011; Lehtovirta-Morley et al., 2011; Pratscher et al., 2011; Tourna et al., 2011; Xia et al., 2011; Zhang et al., 2012) could not detect activity by organisms associated with clade A. By contrast, the closely related clades B and Nitrososphaera, as well as clade $\mathrm{D}$, could be linked to $\mathrm{NH}_{3}$ oxidation. However, the possibility of heterotrophic nitrification cannot be excluded, as no selective inhibitor tests (with for example, acetylene) were performed. One also has to keep in mind that urea represents an alternative substrate for AOA, as was recently shown for Ca. N. viennensis (Tourna et al., 2011) and for AOA in acidic soils (Lu et al., 2012; Lu and Jia, 2012). Although urea was not tested in the potential nitrification assays or enrichment cultures, our observations based on in situ gross nitrification rates are independent of the nature of the substrate.

Although none of the $\mathrm{NH}_{3}$ oxidizer communities studied here was dominated by AOA from clade C, their continuous culturing under selective conditions for autotrophic $\mathrm{NH}_{3}$ oxidizers provides evidence for $\mathrm{NH}_{3}$-dependent growth in this so far uncharacterized major lineage of AOA ('Nitrososphaera-sister cluster' in (Pester et al., 2012)). The estimated cell-specific nitrification rate of $0.21 \mathrm{fmol}$ $\mathrm{N}_{\text {cell }}{ }^{-1} \mathrm{~h}^{-1}$ in the enrichment cultures is comparable, albeit lower, than the value for $\mathrm{Ca} . \mathrm{N}$. viennensis ( $1.63 \mathrm{fmol} \mathrm{Ncell}^{-1} \mathrm{~h}^{-1}$ ), which is also reflected by the longer growth period $(\sim 500 \mu \mathrm{M}$ $\mathrm{NO}_{2}^{-}$produced in $\sim 70$ days) (Figure 4 ). Our results demonstrate, for the first time, $\mathrm{NH}_{3}$ oxidation in this widespread thaumarchaeal lineage represented by the reference fosmid clone 29i4 (Quaiser et al., 2002), which has not been previously linked to any activity or functional gene marker, such as amoA. Growth of organisms from this lineage was recently suggested to be stimulated by organic substrate amendment (that is, root extracts) in temperate soils (Xu et al., 2012). However, the authors doubted their capability to oxidize $\mathrm{NH}_{3}$, as they could not associate amo $A$ genes to their respective 16S rRNA sequences, possibly owing to PCR primer biases.

In conclusion, our study provides evidence that the distinct AOA clades defined here, which encompass the great majority of the AOA diversity found in soils, were not functionally redundant. Therefore, categorical assumptions on the wholegroup level (that is, AOA) (for example, (Di et al., 2009; Banerjee and Siciliano, 2012)) might lead to inconclusive or misleading conclusions.

\section{Role of AOA in nitrification and functioning of Arctic soil ecosystems}

Nitrification is a critical process for $\mathrm{N}$ availability in N-limited Arctic soils (Giblin et al., 1991; Jonasson and Michelsen, 1996), although net nitrification has been shown to be low in these low-temperature ecosystems (Atkin, 1996). By contrast, gross nitrification rates in the present soils were surprisingly high and comparable to rates in soils from warmer climatic zones (Booth et al., 2005). In addition to temperature, $\mathrm{pH}$ has been suggested to regulate $\mathrm{NH}_{4}^{+}$ and $\mathrm{NO}_{3}^{-}$pools in Arctic soils through nitrification (Atkin, 1996). By contrast, the gross nitrification rates here exhibited a high variability that was irrespective of differences in $\mathrm{pH}$ and $\mathrm{NO}_{3}^{-} / \mathrm{NH}_{4}^{+}$ ratios. Furthermore, the highest gross nitrification rates were observed in the wet soils, in contrast to what has been reported for net nitrification in other Arctic soils (Chapin, 1996). However, these and most other Arctic soil studies to date analyzed only net nitrification and, to our knowledge, only one previous study determined gross nitrification through a ${ }^{15} \mathrm{~N}$ pool dilution method, as done here, 
showing also great discrepancies with the corresponding net rates (Binkley et al., 1994). Furthermore, gross and net nitrification responded differently to $\mathrm{NH}_{4}^{+}$amendment in the different soils dominated by distinct AOA clades, showing that, together with the $\mathrm{N}$ preferences of the soil microbiota, the activity potential of the nitrifier populations strongly affects the balance between the two major bio-available inorganic $\mathrm{N}$-forms (that is, $\mathrm{NH}_{4}^{+}$and $\mathrm{NO}_{3}^{-}$). Together, these observations support the idea that nitrification rates are possibly more directly dependent on nitrifier population structure and physiologic, or metabolic, properties than on abiotic factors and underline the importance of linking gross biochemical processes to their microbial catalysers. The different responses of the AOA clades to higher $\mathrm{NH}_{4}^{+}$availability further suggested that the distribution of functionally heterogeneous AOA is likely to play a critical role in the response of soil nitrification to environmental changes, not only in the Arctic but also in soils from other regions. It will, therefore, be crucial to differentiate the AOA populations in future studies assessing the effect of environmental changes on soil nitrification, as well as the direct and indirect contribution of these populations to $\mathrm{N}_{2} \mathrm{O}$ emissions (Santoro et al., 2011).

\section{Conflict of interest}

The authors declare no conflict of interest.

\section{Acknowledgements}

We thank Vigdis Torsvik (Bergen, Norway) and Peter Frenzel (Marburg, Germany) for helping with the field work and suggestions regarding sampling sites, Margarete Watzka and Lucia Fuchslueger (Vienna, Austria) for IRMS and DOC/TDN measurements, respectively. We thank Siegrun Ertl (Vienna, Austria) for providing the Zackenberg samples, Alexander Tveit (Tromsø, Norway) for help in field work and for providing DNA extracts from the peat samples and Nikolaj Lashchinskiy (Novosibirsk, Russia) for site characterization. We thank also Maria Mooshammer (Vienna, Austria) for helping with statistical analyses and figure preparation. The sampling expedition to Spitsbergen (Svalbard) was partially supported by Grant 191696/V49 of the Norwegian Research Council. The experimental work was supported by ESF-project 'CryoCARB' and by projects P23000 and P25369 from the Austrian Science Fund.

\section{References}

Arp DJ, Chain PSG, Klotz MG. (2007). The impact of genome analyses on our understanding of ammoniaoxidizing bacteria. Annu Rev Microbiol 61: 503-528.

Atkin OK. (1996). Reassessing the nitrogen relations of Arctic plants: a mini-review. Plant Cell Environ 19: $695-704$.
Banerjee S, Siciliano SD. (2012). Factors driving potential ammonia oxidation in Canadian arctic ecosystems: does spatial scale matter? Appl Environ Microbiol 78: 346-353.

Bates ST, Berg-Lyons D, Caporaso JG, Walters WA, Knight R, Fierer N. (2011). Examining the global distribution of dominant archaeal populations in soil. ISME $J \mathbf{5}$ : 908-917.

Biasi C, Meyer H, Rusalimova O, Hammerle R, Kaiser C, Baranyi $\mathrm{C}$ et al. (2008). Initial effects of experimental warming on carbon exchange rates, plant growth and microbial dynamics of a lichen-rich dwarf shrub tundra in Siberia. Plant Soil 307: 191-205.

Binkley D, Stottlemyer R, Suarez F, Cortina J. (1994). Soil nitrogen availability in some Arctic ecosystems in northwest Alaska: responses to temperature and moisture. Ecoscience 1: 64-70.

Blainey PC, Mosier AC, Potanina A, Francis CA, Quake SR. (2011). Genome of a low-salinity ammonia-oxidizing archaeon determined by single-cell and metagenomic analysis. PloS One 6: e16626.

Booth MS, Stark JM, Rastetter E. (2005). Controls on nitrogen cycling in terrestrial ecosystems: a synthetic analysis of literature data. Ecol Monogr 75: 139-157.

Brochier-Armanet C, Boussau B, Gribaldo S, Forterre P. (2008). Mesophilic Crenarchaeota: proposal for a third archaeal phylum, the Thaumarchaeota. Nat Rev Microbiol 6: 245-252.

Canfield DE, Glazer AN, Falkowski PG. (2010). The evolution and future of Earth's nitrogen cycle. Science 330: 192-196.

Chapin DM. (1996). Nitrogen mineralization, nitrification, and denitrification in a high Arctic lowland ecosystem, Devon Island, N.W.T., Canada. Arctic Alpine Res 28: 85-92.

Chapin FS III, McGuire A, Randerson J, Pielkesr S, Baldocchi D, Hobbie S et al. (2000). Arctic and boreal ecosystems of western North America as components of the climate system. Global Change Biol 6: 211-223.

Clarke KR, Ainsworth M. (1993). A method of linking multivariate community structure to environmental variables. Mar Ecol Prog Ser 92: 205-219.

Conrad R. (1996). Soil microorganisms as controllers of atmospheric trace gases $\left(\mathrm{H}_{2}, \mathrm{CO}, \mathrm{CH}_{4}, \mathrm{OCS}, \mathrm{N}_{2} \mathrm{O}\right.$, and NO). Microbiol Rev 60: 609-640.

de la Torre JR, Walker CB, Ingalls AE, Konneke M, Stahl DA. (2008). Cultivation of a thermophilic ammonia oxidizing archaeon synthesizing crenarchaeol. Environ Microbiol 10: 810-818.

Di HJ, Cameron KC, Shen JP, Winefield CS, O’Callaghan M, Bowatte $S$ et al. (2009). Nitrification driven by bacteria and not archaea in nitrogen rich grassland soils. Nat Geosci 2: 621-624.

Giblin AE, Nadelhoffer KJ, Shaver GR, Laundre JA, Mckerrow AJ. (1991). Biogeochemical diversity along a riverside toposequence in Arctic Alaska. Ecol Monogr 61: 415-435.

Glaser K, Hackl E, Inselsbacher E, Strauss J, Wanek W, Zechmeister-Boltenstern S et al. (2010). Dynamics of ammonia-oxidizing communities in barley-planted bulk soil and rhizosphere following nitrate and ammonium fertilizer amendment. FEMS Microbiol Ecol 74: 575-591.

Großkopf R, Stubner S, Liesack W. (1998). Novel euryarchaeotal lineages detected on rice roots and in the anoxic bulk soil of flooded rice microcosms. Appl Environ Microbiol 64: 4983-4989. 
Gubry-Rangin C, Hai B, Quince C, Engel M, Thomson BC, James $P$ et al. (2011). Niche specialization of terrestrial archaeal ammonia oxidizers. Proc Natl Acad Sci USA 108: 21206-21211.

Hatzenpichler R, Lebedeva EV, Spieck E, Stoecker K, Richter A, Daims $\mathrm{H}$ et al. (2008). A moderately thermophilic ammonia-oxidizing crenarchaeote from a hot spring. Proc Natl Acad Sci USA 105: 2134-2139.

Hood-Nowotny R, Hinko-Najera Umana N, Inselbacher E, Oswald- Lachouani P, Wanek W. (2010). Alternative methods for measuring iorganic, organic, and total dissolved nitrogen in soil. Soil Sci Soc Am J 74: 1018.

Horz HP, Barbrook A, Field CB, Bohannan BJ. (2004). Ammonia-oxidizing bacteria respond to multifactorial global change. Proc Natl Acad Sci USA 101: 15136-15141.

Ingalls AE, Shah SR, Hansman RL, Aluwihare LI, Santos GM, Druffel ERM et al. (2006). Quantifying archaeal community autotrophy in the mesopelagic ocean using natural radiocarbon. Proc Natl Acad Sci USA 103: 6442-6447.

Inselsbacher E, Cambui CA, Richter A, Stange CF, Mercier H, Wanek W. (2007). Microbial activities and foliar uptake of nitrogen in the epiphytic bromeliad Vriesea gigantea. New Phytol 175: 311-320.

Intergovernmental Panel on Climate Change (2007). Contribution of Working Group $I$ to the Fourth Assessment Report of the Intergovernmental Panel on Climate Change. Cambridge University Press: Cambridge and New York, USA.

Jia Z, Conrad R. (2009). Bacteria rather than Archaea dominate microbial ammonia oxidation in an agricultural soil. Environ Microbiol 11: 1658-1671.

Jonasson S, Michelsen A. (1996). Nutrient cycling in subarctic and Arctic ecosystems, with special reference to the Abisko and Torneträsk region. Ecol Bull 45: 45-52.

Jung MY, Park SJ, Min D, Kim JS, Rijpstra WI, Sinninghe Damste JS et al. (2011). Enrichment and characterization of an autotrophic ammonia-oxidizing archaeon of mesophilic crenarchaeal group I.1a from an agricultural soil. Appl Environ Microbiol 77: 8635-8647.

Junier P, Kim OS, Molina V, Limburg P, Junier T, Imhoff JF et al. (2008). Comparative in silico analysis of PCR primers suited for diagnostics and cloning of ammonia monooxygenase genes from ammonia-oxidizing bacteria. FEMS Microbiol Ecol 64: 141-152.

Kelly JJ, Policht K, Grancharova T, Hundal LS. (2011). Distinct responses in ammonia-oxidizing archaea and bacteria after addition of biosolids to an agricultural soil. Appl Environ Microbiol 77: 6551-6558.

Könneke M, Bernhard AE, de la Torre JR, Walker CB, Waterbury JB, Stahl DA. (2005). Isolation of an autotrophic ammonia-oxidizing marine archaeon. Nature 437: 543-546.

Lamb E, Han S, Lanoil B, Henryz G, Brummell M, Banerjee $S$ et al. (2011). A high Arctic soil ecosystem resists long-term environmental manipulations. Global Change Biol 17: 3187-3194.

Lehtovirta-Morley LE, Stoecker K, Vilcinskas A, Prosser JI, Nicol GW. (2011). Cultivation of an obligate acidophilic ammonia oxidizer from a nitrifying acid soil. Proc Natl Acad Sci USA 108: 15892-15897.

Leininger S, Urich T, Schloter M, Schwark L, Qi J, Nicol GW et al. (2006). Archaea predominate among ammonia-oxidizing prokaryotes in soils. Nature 442: 806-809.

Lu L, Han W, Zhang J, Wu Y, Wang B, Lin X et al. (2012). Nitrification of archaeal ammonia oxidizers in acid soils is supported by hydrolysis of urea. ISME $J \mathbf{6}$ : 1978-1984.

$\mathrm{Lu} \mathrm{L,} \mathrm{Jia} \mathrm{Z.} \mathrm{(2012).} \mathrm{Urease} \mathrm{gene-containing} \mathrm{Archaea}$ dominate autotrophic ammonia oxidation in two acid soils. Environ Microbiol 1-15 (Epub ahead of print).

Ma WK, Schautz A, Fishback LAE, Bedard-Haughn A, Farrell RE, Siciliano SD. (2007). Assessing the potential of ammonia oxidizing bacteria to produce nitrous oxide in soils of a high arctic lowland ecosystem on Devon Island, Canada. Soil Biol Biochem 39: 2001-2013.

Mack MC, Schuur EA, Bret-Harte MS, Shaver GR, Chapin FS III. (2004). Ecosystem carbon storage in arctic tundra reduced by long-term nutrient fertilization. Nature 431: 440-443.

Martens-Habbena W, Berube PM, Urakawa H, de la Torre JR, Stahl DA. (2009). Ammonia oxidation kinetics determine niche separation of nitrifying Archaea and Bacteria. Nature 461: 976-979.

Martikainen PJ. (1985). Nitrous oxide emission associated with autotrophic ammonium oxidation in acid coniferous forest soil. Appl Environ Microbiol 50: 1519-1525.

Mathieu O, Hénault C, Lévêque J, Baujard E, Milloux MJ, Andreux F. (2006). Quantifying the contribution of nitrification and denitrification to the nitrous oxide flux using $15 \mathrm{~N}$ tracers. Environ Pollut 144: 933-940.

Mußmann M, Brito I, Pitcher A, Sinninghe Damsté JS, Hatzenpichler R, Richter A et al. (2011). Thaumarchaeotes abundant in refinery nitrifying sludges express amoA but are not obligate autotrophic ammonia oxidizers. Proc Natl Acad Sci USA 108: 16771-16776.

Nemergut DR, Townsend AR, Sattin SR, Freeman KR, Fierer N, Neff JC et al. (2008). The effects of chronic nitrogen fertilization on alpine tundra soil microbial communities: implications for carbon and nitrogen cycling. Environ Microbiol 10: 3093-3105.

Nordin A, Schmidt IK, Shaver GR. (2004). Nitrogen uptake by Arctic soil microbes and plants in relation to soil nitrogen supply. Ecology 85: 955-962.

Ochsenreiter T, Selezi D, Quaiser A, Bonch-Osmolovskaya L, Schleper C. (2003). Diversity and abundance of Crenarchaeota in terrestrial habitats studied by $16 \mathrm{~S}$ RNA surveys and real time PCR. Environ Microbiol 5: 787-797.

Pester M, Rattei T, Flechl S, Grongroft A, Richter A, Overmann J et al. (2012). amoA-based consensus phylogeny of ammonia-oxidizing archaea and deep sequencing of amoA genes from soils of four different geographic regions.. Environ Microbiol 14: 525-539.

Pratscher J, Dumont MG, Conrad R. (2011). Ammonia oxidation coupled to CO2 fixation by archaea and bacteria in an agricultural soil. Proc Natl Acad Sci USA 108: 4170-4175.

Prosser JI, Nicol GW. (2008). Relative contributions of archaea and bacteria to aerobic ammonia oxidation in the environment. Environ Microbiol 10: 2931-2941.

Quaiser A, Ochsenreiter T, Klenk HP, Kletzin A, Treusch AH, Meurer G et al. (2002). First insight into the genome of an uncultivated crenarchaeote from soil. Environ Microbiol 4: 603-611. 
Ravishankara AR, Daniel JS, Portmann RW. (2009). Nitrous oxide $\left(\mathrm{N}_{2} \mathrm{O}\right)$ : the dominant ozone-depleting substance emitted in the 21st century. Science 326: 123-125.

Reed HE, Martiny JB. (2007). Testing the functional significance of microbial composition in natural communities. FEMS Microbiol Ecol 62: 161-170.

Rotthauwe JH, Witzel KP, Liesack W. (1997). The ammonia monooxygenase structural gene amoA as a functional marker: molecular fine-scale analysis of natural ammonia-oxidizing populations. Appl Environ Microbiol 63: 4704-4712.

Sala O, Chapin FS III, Armesto J, Berlow E, Bloomfield J, Dirzo R et al. (2000). Global Biodiversity scenarios for the year 2100. Science 287: 1770-1774.

Santoro AE, Buchwald C, McIlvin MR, Casciotti KL. (2011). Isotopic signature of $\mathrm{N}_{2} \mathrm{O}$ produced by marine ammonia-oxidizing archaea. Science 333: 1282-1285.

Schauss K, Focks A, Leininger S, Kotzerke A, Heuer H, Thiele-Bruhn S et al. (2009). Dynamics and functional relevance of ammonia-oxidizing archaea in two agricultural soils. Environ Microbiol 11: 446-456.

Schleper C, Nicol GW. (2010). Ammonia-oxidising archaea-physiology, ecology and evolution. Adv Microb Physiol 57: 1-41.

Schuur EA, Vogel JG, Crummer KG, Lee H, Sickman JO, Osterkamp TE. (2009). The effect of permafrost thaw on old carbon release and net carbon exchange from tundra. Nature 459: 556-559.

Schuur EAG, Bockheim J, Canadell JG, Euskirchen E, Field CB, Goryachkin SV et al. (2008). Vulnerability of permafrost carbon to climate Change: implications for the gobal carbon cycle. Bioscience 58: 701-714.

Shaver GR, Chapin FS III. (1980). Response to fertilization by various plant-growth forms in an Alaskan tundranutrient accumulation and growth. Ecology 61: 662-675.

Siciliano SD, Ma WK, Ferguson S, Farrel RE. (2009). Nitrifier dominance of Arctic soil nitrous oxide emissions arises due to fungal competition with denitrifiers for nitrate. Soil Biol Biochem 41: 1104-1110.

Singh BK, Bardgett RD, Smith P, Reay DS. (2010). Microorganisms and climate change: terrestrial feedbacks and mitigation options. Nat Rev Microbiol 8: 779-790.

Stephen JR, Chang YJ, Macnaughton SJ, Kowalchuk GA, Leung KT, Flemming CA et al. (1999). Effect of toxic metals on indigenous soil beta-subgroup proteobacterium ammonia oxidizer community structure and protection against toxicity by inoculated metalresistant bacteria. Appl Environ Microbiol 65: 95-101.

Strickland MS, Lauber C, Fierer N, Bradford MA. (2009). Testing the functional significance of microbial community composition. Ecology 90: 441-451.
Szukics U, Hackl E, Zechmeister-Boltenstern S, Sessitsch A. (2012). Rapid and dissimilar response of ammonia oxidizing archaea and bacteria to nitrogen and water amendment in two temperate forest soils. Microbiol Res 167: 103-109.

Tarnocai C, Canadell JG, Schuur EAG, Kuhry P, Mazhitova G, Zimov S. (2009). Soil organic carbon pools in the northern circumpolar permafrost region. Global Biogeochemical Cycles 23: GB2023.

Tourna M, Freitag TE, Nicol GW, Prosser JI. (2008). Growth, activity and temperature responses of ammonia-oxidizing archaea and bacteria in soil microcosms. Environ Microbiol 10: 1357-1364.

Tourna M, Stieglmeier M, Spang A, Konneke M, Schintlmeister A, Urich $\mathrm{T}$ et al. (2011). Nitrososphaera viennensis, an ammonia oxidizing archaeon from soil. Proc Natl Acad Sci USA 108: 8420-8425.

Treusch AH, Leininger S, Kletzin A, Schuster SC, Klenk HP, Schleper C. (2005). Novel genes for nitrite reductase and Amo-related proteins indicate a role of uncultivated mesophilic crenarchaeota in nitrogen cycling. Environ Microbiol 7: 1985-1995.

Wessén E, Soderstrom M, Stenberg M, Bru D, Hellman M, Welsh A et al. (2011). Spatial distribution of ammoniaoxidizing bacteria and archaea across a 44-hectare farm related to ecosystem functioning. ISME $J$ 5: 1213-1225.

Westermann S, Langer M, Boike J. (2011). Spatial and temporal variations of summer surface temperatures of high-Arctic tundra on Svalbard-implications for MODIS LST based permafrost monitoring. Remote Sens Environ 115: 908-922.

Wuchter C, Abbas B, Coolen MJ, Herfort L, van Bleijswijk $\mathrm{J}$, Timmers $\mathrm{P}$ et al. (2006). Archaeal nitrification in the ocean. Proc Natl Acad Sci USA 103: 12317-12322.

Xia W, Zhang C, Zeng X, Feng Y, Weng J, Lin X et al. (2011). Autotrophic growth of nitrifying community in an agricultural soil. ISME J 5: 1226-1236.

Xu C, Liang C, Wullschleger S, Wilson C, McDowell N. (2011). Importance of feedback loops between soil inorganic nitrogen and microbial communities in the heterotrophic soil respiration response to global warming. Nat Rev Microbiol 9: 222.

Xu M, Schnorr J, Keibler B, Simon HM. (2012). Comparative analysis of $16 \mathrm{~S}$ rRNA and amoA genes from archaea selected with organic and inorganic amendments in enrichment culture. Appl Environ Microbiol 78: 2137-2146.

Zhang LM, Hu HW, Shen JP, He JZ. (2012). Ammoniaoxidizing archaea have more important role than ammonia-oxidizing bacteria in ammonia oxidation of strongly acidic soils. ISME J 6: 1032-1045.

Supplementary Information accompanies this paper on The ISME Journal website (http://www.nature.com/ismej) 